\title{
WADAH INTERAKSI SOSIAL
}

\author{
Yonathan Yoel Mulyadi ${ }^{1)}$, Franky Liauw ${ }^{21}$ \\ 1)Program Studi S1 Arsitektur, Fakultas Teknik, Universitas Tarumanagara, yonathanyoel97@gmail.com \\ 2) Program Studi S1 Arsitektur, Fakultas Teknik, Universitas Tarumanagara, frankyl@ft.untar.ac.id
}

\begin{abstract}
Abstrak
Manusia senantiasa melakukan hubungan dan pengaruh timbal balik dengan manusia yang lain dalam rangka memenuhi kebutuhan dan mempertahankan kehidupannya. Adanya aksi reaksi merupakn sebuah bentuk interaksi yang diciptakan oleh manusia, karena manusia merupakan mahkluk sosial yang tidak dapat hidup tanpa bantuan orang lain. Tujuan penelitian ini untuk mengetahui pola komunikasi yang dibangun oleh para masyarakat dan untuk mengetahui proses integrasi sosial yang dilakukan. Proses pengumpulan data menggunakan metode observasi yang dilakukan dalam jangka waktu 5 hari di area tapak studi, selain itu juga metode wawancara dilakukan untuk memperoleh data yang lebih akurat dalam meninjau perkembangan masyarakat. Berdasarkan hasil penelitian, pola interaksi yang dibangun oleh masyarakat di Kramat tergolong kurang baik, karena hampir seluruh aktivitas masyarakat dilakukan di kantor, sekolah maupun tempat bekerja lainnya. Terdapat komunitas sosial yang bergerak dalam bidang seni kriya akan tetapi maksyarakat sekitar kurang meminatinya karena keterbatasan waktu dan juga lokasi yang kurang strategis, selain itu juga karena bersifat komersial ada beberapa masyarakat yang kurang meminatinya. Wadah belajar dan interaksi sosial sebagai pengembangan jaringan di kramat merupakan fasilitas sosial yang dapat diakses oleh seluruh kalangan masyarakat tanpa melihat status sosialnya. Fasilitas yang disediakan merupakan hasil dari data wawancara dengan masyarakat sekitar sebagai dasar dalam menciptakan proyek ini. Wadah sosial merupakan sebuah fasilitas yang diberikan kepada masyarakat tanpa memungut biaya dalam ketentuan tertentu untuk masyarakat dapat berekreasi serta bertukar pikiran dan juga ilmu dalam bidang - bidang tertentu.
\end{abstract}

Kata kunci: fasilitas; interaksi; kelompok; masyarakat; sosial

\begin{abstract}
People always engage in mutual relations and influence with other human beings in order to fulfill their needs and sustain their lives. The reaction action is a form of interaction created by humans, because humans are social beings who cannot live without the help of others. The purpose of this research is to know the pattern of communication built by the community and to know the process of social integration. The process of collecting data using the observation method conducted within 5 days in the study site area, and the interview method is conducted to obtain more accurate data in reviewing community development. Based on the results of the research, the pattern of interaction built by the community in Kramat is less good, because the whole community activities are done in the Office, school or other workplace. There is a social community that is engaged in the art of craft, but there are less people in the field because of limited time and location is less strategic, but also because it is commercial there are some people who lack It. Intersocial learning and network development in Kramat is a social facility that can be accessed by the whole community without seeing the social status. The facilities provided are the result of the interview data with the surrounding community as the basis for creating this project. Social containers are a facility provided to the community without charging a fee in certain provisions for the Community can be recreation and brainstorm and also knowledge in certain areas.
\end{abstract}

Keywords: facilities; group; interaction; people; social 


\section{PENDAHULUAN}

Interaksi sosial adalah hubungan timbal balik yang saling mempengaruhi. Ada aksi dan ada reaksi. Pelakunya lebih dari satu, individu dengan individu, individu dengan kelompok, kelompok dengan kelompok. Interaksi sosial memerlukan syarat yaitu kontak sosial dan juga komunikasi sosial. Kontak sosial dapat berupa kontak primer dan kontak sekunder, sedangkan komunikasi sosial dapat secara langsung apabila tanpa melalui perantara. Misalnya A dan B bercakap - cakap termasuk contoh dari interaksi sosial secara langsung, sedangkan apabila A menitip salam lewat B dan B meneruskan kembali ke A, ini merupakan contoh interaksi sosial secara tidak langsung.

Menurut Syam (2013: 95) bahwa dalam komunikasi ada tiga unsur penting yang selalu ada, yaitu sumber informasi (source), saluran (channel), dan penerima informasi (receiver). Sumber informasi adalah seseorang atau intitusi yang memiliki bahan informasi (pemberitaan) untuk disebarkan kepada masyarakat luas. Saluran (channel) yang digunakan, dapat berupa saluran intrapersonal atau pun media massa. Sementara penerima informasi (receiver) adalah perorangan atau kelompok dan masyarakat yang menjadi sasaran informasi atau yang menerima informasi.

Faktor yang mendasari terjadinya interaksi sosial meliputi imitasi, sugesti, identifikasi, indentifikasi, simpati dan empatai imitasi adalah interaksi sosial yang didasari oleh faktor meniru orang lain. Setiap masyarakat manusia selama hidup pasti mengalami perubahan-perubahan. Perubahan dapat berupa perubahan yang tidak menarik dalam arti kurang mencolok, ada juga perubahan-perubahan yang lambat sekali, akan tetapi ada juga berjalan dengan cepat.

Kebutuhan program yang disediakan merupakan hasil yang diperoleh lewat wawancara dan juga observasi lokasi secara rutin. Terdapat beberapa hal yang menjadi poin penting dalam penentuan program kegiatan ini, salah satunya kurang tersedianya area sosial masyarakat sebagai wadah untuk berkomunikasi bersama. Selain itu juga akibat kepadatan penduduk dan juga area komersial yang memadati kawasan Kramat, maka area hijau juga semakin menipis dan tergolong kurang.

Perubahan-perubahan hanya dapat ditemukan oleh seseorang yang sempat meneliti susunan dan kehidupan suatu masyarakat pada suatu waktu dan membandingkannya dengan susunan dan kehidupan msyarakat tersebut pada waktu yang lampau. Perubahan - perubahan masyarakat dapat meliputi nilai-nilai sosial, norma-norma sosial, pola perilaku organisasi, susunan kelembagaan masyarakat, kekuasaan dan wewenang.

Berdasarkan latar belakang diatas diketahui terdapat masalah yang terjadi, yaitu:

- Terdapat isu mengenai kurangnya interaksi masyarakat yang terus meningkat dari tahun ke tahun

- Masalah interaksi sosial yang disebabkan oleh padatnya jadwal kegiatan dan juga tidak adanya fasilitas umum yang dapat mewadahi kegiatan sosial yang bersifat interaktif

Keberadaan wadah sosial yang dapat mengikat antara masyarakat merupakan sebuah kebutuhan bagi setiap individu, akan tetapi dengan padatnya aktivitas pada pagi hingga sore hari mengakibatkan kurangnya interaksi antara penduduk.

\section{KAJIAN LITERATUR}

Interaksi merupakan sebuah aktivitas yang memadukan lebih dari satu individu, manusia merupakan mahkluk sosial yang memerlukan orang lain. Dengan menggunakan konsep ini maka hubungan relasi antara manusia dapat dijadikan sebuah konsep dalam menciptakan bangunan, secara psikologis banyak terjadi interaksi secara batin dalam hidup manusia. Akan tetapi akhirakhir ini manusia mulai digantikan dengan adanya teknologi, tetapi seharusnya manusia yang perlu mengendalikan teknologi itu sendiri.

Menurut Rogers (1994) dalam buku The History of Communication Study desain organisasi harus memungkinkan terjadinya komunikasi 4 arah yang berbeda, yaitu: 
- Komunikasi ke bawah (down ward communication) adalah komunikasi yang mengalir dari tingkat atas ke tingkat bawah dalam sebuah organisasi seperti kebijakan pimpinan, instansi/memoresmi.

- Komunikasi keatas (upward communication) adalah komunikasi yang mengalir dari tingkat bawah ke tingkat atas sebuah organisasi seperti kotak saran, pertemuan kelompok dan prosedur keluhan.

- Komunikasi horizontal (horizontal communication) adalah komunikasi yang mengalir melintasi berbagai fungsi dalam organisasi.

- Komunikasi diagonal (diagonal communication) adalah komunikasi yang bersifat melintasi fungsi dan tingkatan dalam organisasi.

Keberadaan third place ditujukan sebagai fungsi tersier (pelengkap) dalam aktivitas sehari hari, menurut Oldenburg (1989) terdapat beberapa poin penting yang harus ada didalam third place, yaitu:

- Neutral ground: Pengunjung bebas mengakses tempat tanpa hambatan apapun

- Leveler (a leveling place): Tidak terikat dengan status sosial.

- Conversation is the main activity: Pembicaraan yang menyenangkan antar individu

- Accessibility and accommodation: Dapat memenuhi kebutuhan penggunanya

- The regulars: Pengunjung lama dapat menarik pengunjung baru

- A low profile: Tidak mahal dan sederhana

- The mood is playful: Memiliki sifat yang menyenangkan

- A home away from home: Spiritual regeneration

Third place memiliki kekhasan yang berbeda dengan third place di tempat lain, termasuk didalamnya adalah ruang dan program yang terjadi di dalam third place. Third place merupakan bagian dari komunitas, karena itu aksebilitas menjadi hal penting. Aksebilitas sangat diperlukan, karena itu posisi terhadap komunitas menjadi perlu, bahkan terkadang third place memiliki posisi penting dari kantor pemerintahan. third place sebagai tempat dimana masyarakat berkumpul, dan memiliki status yang sama sehingga third place menjadi tempat netral, dan sederhana.

Control (kendali) merupakan teori yang berujung kepada perintah untuk mengendalikan suatu pikiran dalam alam bawah sadar manusia. Kendali yang merupakan pusat untuk melakukan segala rangkaian aktivitas, dalam kategori ini pola kendali tiap manusia memiliki pola yang beragam untuk dapat dimengerti karena faktor psikologi juga mempengaruhinya. Ketertarikan manusia didasari oleh rasa ingin tahu yang tinggi, hingga menimbulkan sebuah gagasan dalam pikirannya untuk menelusuri lebih jauh. Sifat tersebut dapat menimbulkan efek yang baik dan juga buruk, tergantung kepada sifat dan karakter manusia.

\section{Ide Konsep}

Perekonimian di Indonesia memiliki potensi dalam bidang penyedia jasa yang merupakan sebuah target pasar dalam mempersiapkan Sumber Daya Manusia (SDM) untuk mampu bersaing di dunia pekerjaan, selain itu juga dengan mempelajari soft dan hard skill merupakan bekal untuk dapat bersaing dan berkembang pada era modern ini. Dengan perkembangan teknologi modern saat ini banyak kemudahan yang diberikan untuk mencapai tujuan yang diinginkan, selain itu juga lewat media sosial manusia dapat mengakses berbagai macam informasi sesuai dengan kebutuhannya.

Usulan program yang diberikan mengacu pada fenomena yang terjadi pada masyarakat sekitar yaitu kurangnya interaksi antara sesama penduduk yang memunculkan sifat individualis masyarakat. Program yang disajikan merupakan hasil dari analisa, wawancara dan juga survei tapak studi terpilih. 


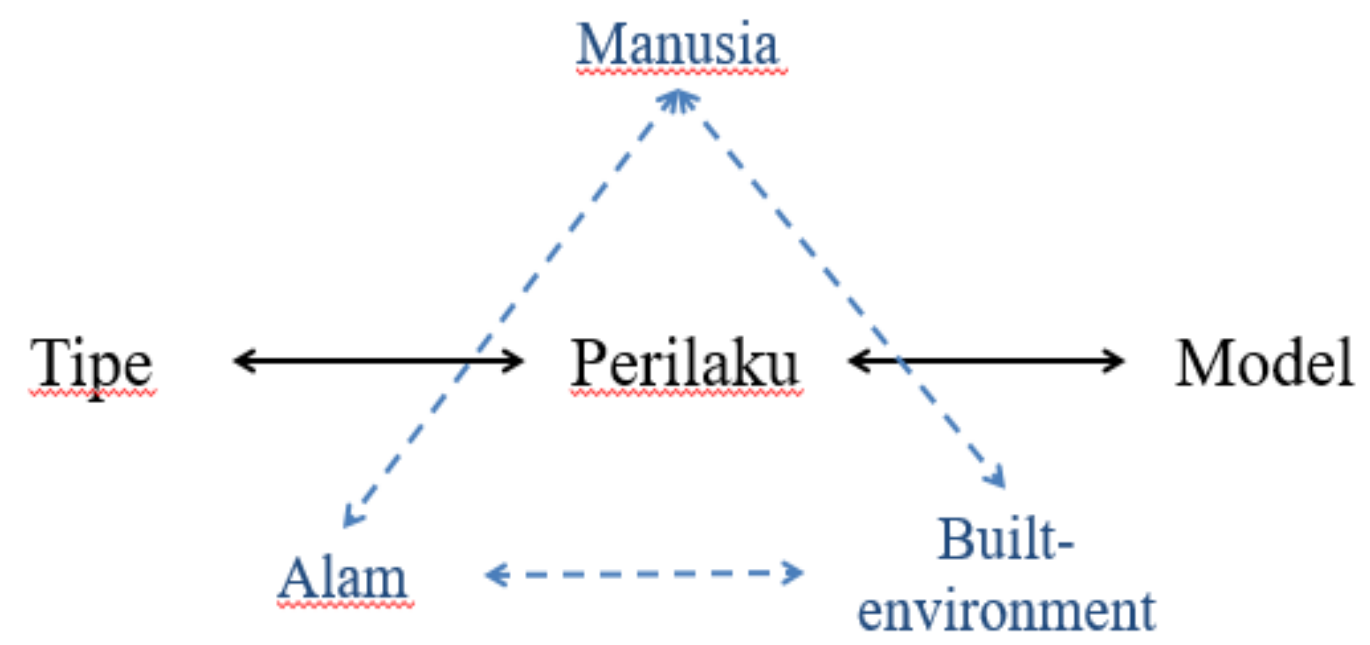

Gambar 1. Diagram hubungan tipe, perilaku dan model menurut Yoshiharu Tsukamoto Sumber: https://www.titech.ac.jp/english/research/stories/faces25_tsukamoto.html

Perilaku manusia merupakan acuan yang mendasar dalam menciptakan karya arsitektur karena manusia merupakan pencipta dan sekaligus juga pengguna. Dalam menyalurkan ide yang ingin dicapai dalam sebuah karya arsitektur, haruslah memahami bagaimana cara kerja ruang dan waktu. Karena dalam teori time and space keberadaan sebuah ruang yang diiptakan dalam waktu tertentu merupakan sebuah perjalanan cara manusia berpikir atau memahami ruang sebagai wadah untuk memfasilitasi sebuah kegiatan.

Kota dapat disimpulkan bahwa ada banyak kota dalam waktu yang sama dan kota lain di kota setiap saat. Ini memberikan arti bagaimana sebuah kota berkembang dengan begitu pesat untuk mencapai sebuah keberhasilan dan dalam waktu yang bersamaan juga kota lain berusaha untuk dapat berkembang. Semua ini dipicu dengan perilaku manusia yang cenderung ingin meningkatkan kualitas kota demi kebutuhan masyarakat untuk mencapai titik keberhasilan. Dalam sebuah kota terdapat berbagai macam kalangan yang memiliki golongan - golongan tertentu, ada yang menengah keatas dan ada juga yang menengah kebawah. Setiap golongan juga memiliki budaya yang berbeda - beda dalam beraktivitas dan juga berkomunikasi.

Akan tetapi sangat disayangkan bahwa terjadi kesenjangan sosial karena perbedaan status, dalam konteks ini third place merupakan tempat bagi semua kalangan masyarakat tanpa memandang status sosialnya.

\section{Ide Perencanaan}

Minim interaksi masyarakat di perkotaan masyarakat kota cenderung memiliki berbagai macam kesibukan, seperti bekerja, bersekolah, berkuliah dan masih banyak aktivitas lainnya yang memakan waktu dan dilakukan setiap hari. Pada saat seseorang pulang, orang tersebut akan langsung beristirahat karena aktivitas dan kegiatan yang begitu melelahkan. Alternatif yang diberikan sebagai jembatan antara masyarakat agar dapat berkomunikasi merupakan sebuah ruang interaktif yang dapat menumbuhkan sifat sosial dan kepekaan antara sesama.

Perkembangan teknologi perlahan - lahan menggantikan kehadiran fisik manusia dengan ada nya sosial media sebagai perangkat untuk berinteraksi antara sesama yang mungkin berada jauh dari lokasi tertentu. Akan tetapi dengan adanya teknologi yang menjadi candu bagi masyarakat perkotaan, menumbuhkan nilai individualis yang tidak peduli dengan sekitar. Pada dasarnya manusia merupakan makhluk sosial dan perlu orang lain untuk dapat terus menjalan hidupnya, teknologi tidak dapat menggantikan esensi fisik manusia berada pada ruang dan waktu tertentu. 


\section{METODE PERANCANGAN}

Dalam proses penulisan tugas akhir ini, terdapat metode pembahasan dengan 4 tahap:

A. Tahap pengumpulan data

B. Penumpulang data dilakukan dengan cara

- Melakukan observasi lapangan terkait dengan tapak studi terpilih

- Melakukan wawancara dengan penduduk

- Melakukan studi pustaka

- Melakukan studi literartur

C. Tahap analisa, metode yang dilakukan dalam melakukan analisa adalah:

-Korelasional, yaitu menarik hubungan antara data dengan menggabungkan fakta yang ada

-Pattern language, yaitu menganalisis melalui data yang ada lalu mengembangkannya untuk menentukan program.

D. Tahap perumusan konsep dari hasil analisa

Data diperoleh melalui BPS (Badan Pusat Statistik), jurnal - jurnal, e-book, wawancara singkat dengan beberapa penduduk lokal kawasan senen yang tinggal menetap pada area tersebut. Narasumber merupakan masyarakat, kepala RT dan juga penjaga toko ( $25-55$ tahun). Selain itu juga diberlakukan survey kepada kawasan studi yang terpilih, serta lokasi yang memiliki program yang sejenis dengan proyek.

\section{DISKUSI DAN HASIL}

\section{Wadah belajar dan interaksi sosial}

Wadah sosial merupakan area yang bersifat umum bagi setiap masyarakat agar dapat mengaksesnya, kebutuhan wadah sosial juga harus dapat memfasilitasi kegiatan masyarakat secara menyeluruh sesuai dengan kebutuhan penduduk. Hal ini disebabkan oleh kurangnya fasilitas sosial yang mewadahi kegiatan masyarakat, program ini dipilih menjadi program utama karena kurangnya fasilitas sosial seperti, lapangan olah raga, pendidikan non-formal, area sosial. Fungsi utama merupakan tempat ketiga, selain itu juga ada fungsi komersial seperti foodcourt dan juga coffee shop sebagai penunjang kebutuhan proyek.

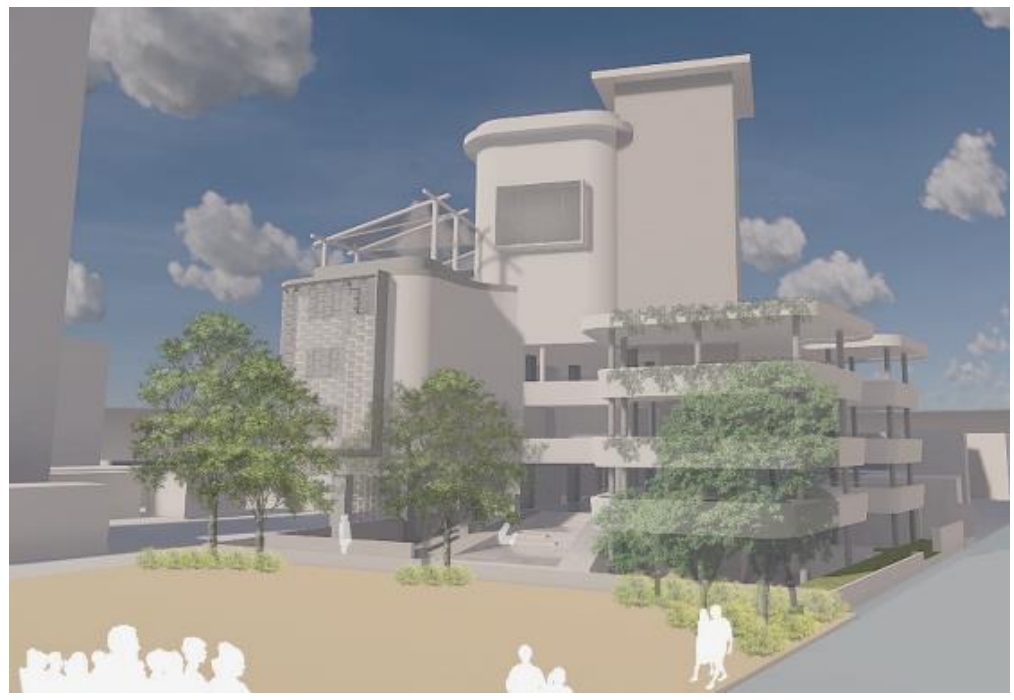

Gambar 2. Ekterior bangunan

Sumber: Penulis, 2019

Bangunan merupakan high-rise building yang dirancang untuk menyamakan ketinggian bangunan dengan sekitarnya, akan tetapi pada bagian muka depan halaman bangunan merupakan open spcae yang diciptakan sebagai area berkumpul sebelum masuk ke dalam bangunan. Fasad bangunan menggunakan wind arbor sebagai kinetic fasad yang memberikan 
sentuhan movement pada fasad bangunan. Interaksi yang diciptakan merupakan antara manusia dengan bangunan, bangunan dijadikan sebagai wadah sedangkan manusia merupakan bagian dari wadah yang memberi kegiatan. Ini merupakan konsep dari bangunan yang diciptakan agar terwujudnya bangunan yang interaktif.

Sebagai wadah kegiatan bangunan ini merupakan ruang sosial yang dapat diakses oleh semua kalangan masyarakat tanpa adanya batasan sosial satu sama lainnya. Komunikasi antara manusia merupakan fokus utama dalam menciptakan wadah sosial ini karena dengan perkembangan zaman yang semakin meningkat maka banyak aktivitas sosial yang mulai tergantikan dengan adanya teknologi. Sebagai contoh dalam komunikasi, kebanyakan masyarakat menggunakan sosial media yang bersifat komunikasi jarak jauh. Dengan adanya sosial media maka tingkat adiktif masyarakat terhadap penggunaan teknologi juga meningkat.

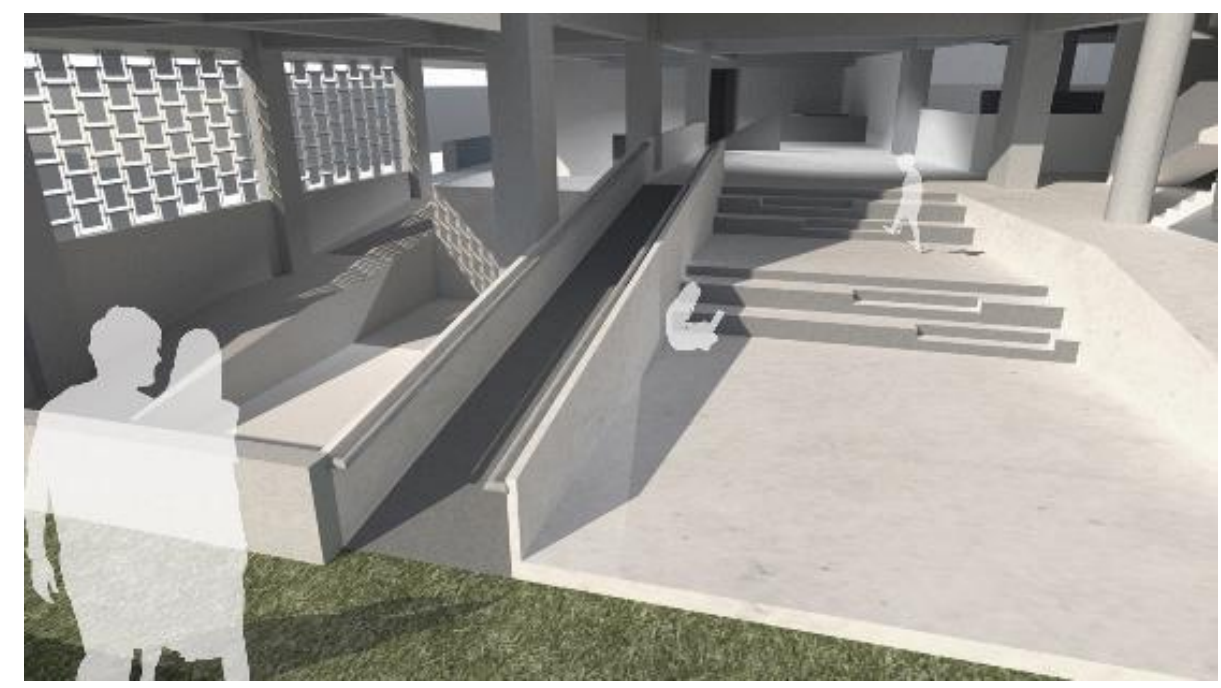

Gambar 3. Area open space bangunan

Sumber: Penulis, 2019

Area ini merupakan ruang terbuka sebagai titik pertemuan dari halaman depan menuju bangunan. Konsep ruang yang ingin dicapai adalah pertemuan antara 2 ruang yang berbeda sebagai perantara untuk masuk ke dalam bangunan, selain itu juga dengan konsep interaktif maka bangunan tidak memiliki banyak dinding yang memberikan kesan terbuka dan juga tidak membatasi antara luar dengan dalam.

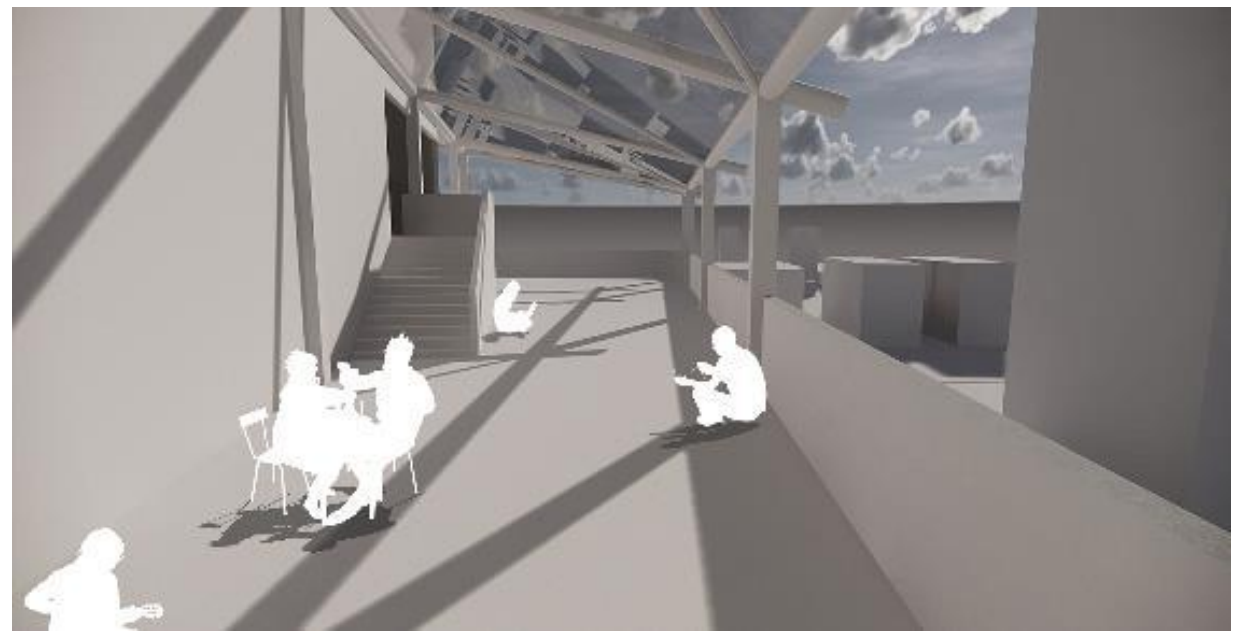

Gambar 4. Area community sharing space

Sumber: Penulis, 2019 


\section{Program Kegiatan}

Wadah Interaksi Sosial sebagai pengembang Jaringan di Kramat memiliki 3 program yaitu:

A. Edutaiment (Edukasi dan Entertaiment) yang menargetkan kepada semua pengunjung dalam belajar bersama untuk memperoleh ilmu yang baru.

- Cooking workshop, area ruang belajar yang memiliki aktivitas utama memasak

- Game area, merupakan sebuah area yang memiliki kegiatan untuk bermain dengan menggunakan teknologi arcade game, aktivitas sosial yang ditumbuhkan lewat game memiliki keterkaitan dalam ketertarikan yang sama antara satu sama lain. Hal ini menciptakan adanya interaksi fisik dengan sesama pemain.

- Arts $n$ craft workshop, area belajar yang memiliki aktivitas mematung dan juga pembuatan kerajinan seni kriya.

- Mini library, interaksi manusia tidak selalu antara individu dengan individu manusia, buku merupakan sumber pengetahuan yang dapat dipakai untuk memperoleh ilmu yang lebih luas selain itu juga dengan membaca dapat juga membuka pola pikir setiap manusia. Konsep ruang yang disajikan dalam area membaca dibuat seinteraktif antar tiap lantai dengan menggunakan sistem split level untuk dapat meningkatkan efisiensi pada tiap lantai kepada pegguna.

B. Sports area (Area berolah raga) yang difokuskan kepada kebugaran dan kesehatan masyarakat dengan mengadakan street basketball court dan juga jogging track.

- Memiliki area street basketball dan juga jogging track

C. Foodcourt dan coffee shop merupakan program yang menjual makanan dan minuman secara komersial sebagai penunjang proyek.

Intersocial network development adalah wadah untuk memfasilitasi kegiatan edukasi yang memiliki fungsi untuk pengenalan, pembelajaran dan juga pengembangan pengetahuan yang sudah diajarkan. Fungsi lain merupakan penunjang untuk memenuhi kebutuhan masyarakat sesuai dengan data yang telah dikumpulkan lewat observasi dan juga wawancara singkat dengan penduduk sekitar.

Wadah interaksi sosial merupakan sebuah community space yang diciptakan untuk menjawab kebutuhan masyarakat setempat dengan keberadaan ruang publik yang dapat diakses oleh seluruh kalangan masyarakat. Masyarakat setempat memiliki rasio pekerja dan juga pelajar yang cukup tinggi, area komersial yang memadati area muka dekat jalan utama merupakan akses yang mudah dicapai bagi penduduk dan juga pengunjung dari luar area Kramat.

Keberadaan bangunan ini merupakan citra sebagai tempat berinteraksi secara sosial tanpa adanya rongga yang memisahkan antara usia dan juga status sosial, selain itu juga bangunan ini memiliki lokasi yang cukup strategis pada kalangan masyarakat yang tinggal pada area Kramat. Untuk menerapkan konsep walkable city sebagai kota yang sehat maka pada area bangunan tidak disediakan parkir untuk memaksimalkan penggunaan kendaraan umum.

\section{KESIMPULAN DAN SARAN}

Penulisan ini bertujuan untuk menggusulkan program pelatihan bagi masyarakat kawasan Kramat dengan metode interaktif untuk meningkatkan kualitas Sumber Daya Manusia (SDM) dari segi edukasi, tetapi juga mendukung aktivitas sosial masyarakat. Dalam pendekatan desain telah dilakukan riset dan studi terkait generasi millennial sebagai salah satu target pengguna program, maka diusahakan desain dapat diterima oleh satu generasi tetapi juga dengan generasi lainnya.

Setelah melalui berbagai tahap dalam merancang proyek, dapat ditarik beberapa poin penting sebagai kesimpulan akhir:

A. Dalam melakukan proses desain memerlukan berbagai tahapan untuk dapat menciptakan desain yang sesuai dengan kebutuhan proyek. Selain itu juga dapat memberikan solusi atau jalan keluar dengan isu yang diangkat. 
B. Kebutuhan ruang publik merupakan salah satu isu yang diangkat, karena keberadaan ruang publik merupakan sarana bagi seluruh kalangan masyarakat untuk dapat beraktivitas tanpa adanya hambatan biaya yang bersifat kolektif.

C. Seorang arsitek yang mempelajari ilmu arsitektur merupakan orang yang dapat memahami kebutuhan setiap individu yang berbeda - beda, dalam mendesain bangunan tindakan yang diambil ialah menggabungkan beberapa macam program kegiatan untuk dapat memenuhi kebutuhan masyarakat agar dapat memaksimalkan fungsi dari tujuan bangunan tersebut.

D. Arsitektur merupakan ilmu yang mempelajari ruang dan waktu, dimana ruang memiliki berbagai fungsi yang bermacam - macam diwaktu yang berbeda juga. Arsitektur tidaklah harus fokus pada satu aliran saja melainkan dapat diolah untuk dapat menyesuaikan dengan kebutuhan pengunjung.

E. Secara keseluruhan, proses perancangan dengan pendekatan komunikatif dapat membuahkan hasil yang akurat sesuai dengan data yang diperoleh lewat wawancara, selain itu dengan melakukan observasi sebagai pendukung data yang sudah diperoleh dan mempelajarinya sesuai aktivitas setiap individu.

\section{REFERENSI}

Erikson, E. (1902). Psychosocial Stages - Simply Psychology. Jerman. Diakses dari https://docuri.com/download/erik-erikson-psychosocial-stages-simplypsychology 59c1e23ff581710b286a64c6 pdf pada tanggal 25 September 2019.

Oldenburg, R. (1989). The Great Good Place. Florida, diakses pada tanggal 18 September 2019. https://www.mnsu.edu/voices/greatgoodplace.pdf

Rogers, E. (1994). The History of Communication Study. lowa, diakses pada tanggal 18 September 2019. https://books.google.co.id/books/about/A History of Communication Study.

Syam, N. (2012). Sosiologi sebagai Akar Ilmu Komunikasi. Bandung: Simbiosa Rekatama Media. 
